http://jmscr.igmpublication.org/home/ ISSN (e)-2347-176x ISSN (p) 2455-0450

crossref DOI: https://dx.doi.org/10.18535/jmscr/v7i11.32

Journal Of Medical Science And Clinical Research

\title{
Pregnancy in Sickle Cell Disease is a Very High-Risk Situation: A Case Control Study
}

\author{
Authors \\ Dr Akanksha Girish Mahajan MD (OBGY) ${ }^{1}$, CIMP, Dr Trupti Nagaria MD (OBGY) ${ }^{2}$, \\ Dr Ruchi Kishore, MD (OBGY) ${ }^{3}$, Dr Chetan Pathak, DMRD, DNB ${ }^{4}$ \\ ${ }^{1}$ Ruby Hall Clinic Hinjewadi \\ ${ }^{2}$ Professor and Head of the department, Department of Obstetrics and Gynecology, Pt JNM Medical \\ College, Raipur \\ ${ }^{3}$ Associate Professor, Department of Obstetrics and Gynecology, Pt. JNM Medical College, Raipur \\ ${ }^{4}$ Consultant Radiologist in Surya Mother and Child Care, Pune \\ *Corresponding Author \\ Dr Akanksha Girish Mahajan MD (OBGY), CIMP
}

\begin{abstract}
Background: A prospective, observational case control study to compare outcome of pregnancy in women with sickle cell disease (SCD) to normal haemoglobin.

Methods: All pregnant women with sickle cell disease who attended department of obstetrics and gynecology, Pt JNM medical college, Raipur were included in study. Age matched controls were included who had normal haemoglobin, in ratio 1:2.. A detailed history was taken. All women were thoroughly examined and were properly followed and managed for any developing complications. Mothers were regularly screened for any developing medical/ obstetric complications throughout pregnancy, during delivery and in postpartum period till the discharge. The fetomaternal outcomes were compared using $P$ value and paired T test whichever was suitable.

Results: Significant number of patients with SCD developed crisis, leg ulcers, AVN hip. Incidence of UTI, pneumonia, anemia, IUGR, severe oligohydramnios, preterm labor, post delivery wound infection were statistically significantly higher among cases as compared to controls. Requirement of blood transfusion, need of ventilatory support, duration of hospital stay, requirement of nursery admission for newborn was higher in cases as compared to controls.

Conclusion: Early booking, meticulous antenatal care and supervised hospital delivery will improve the maternal and fetal outcomes in the pregnant women with sickle cell disease.

Keywords: sickle cell disease, fetomaternal outcome, crisis, blood transfusion, Hb electrophoresis.
\end{abstract}

\section{Introduction}

Sickle cell hemoglobinopathy is the most common inherited condition worldwide. ${ }^{1}$ Estimates showed the trend of increasing number of people with SCD, mostly from developing countries ${ }^{2}$. In 2010 it was estimated that there were more than 100 million sickle cell carriers worldwide and 60,000 people are suffering from sickle cell disease in Chhattisgarh. ${ }^{3}$ There is paucity of data regarding pregnancy outcome of women with sickle cell disease belonging to Chhattisgarh. So the present study was conducted to compare fetomaternal 
outcome in pregnant women with SCD and women who had normal haemoglobin.

SCD comprises a group of diseases characterized by the presence of sickle hemoglobin $(\mathrm{HbS})$. In stress situations like infections, low oxygen tension $\mathrm{HbS}$ solubility decreases, resulting in the polymerization of $\mathrm{HbS}$ molecules .The intracellular formation of $\mathrm{HbS}$ polymers affects the red cell structure, changing it from biconcave to sickle-shaped structure, thereby damaging the cell membrane, making it more rigid and exposing a greater number of adhesion molecules on the cell surface. This increases the adherence of red cells to the vascular endothelium which causes vessel occlusion resulting in tissue ischemia and painful crisis. This phenomenon is also responsible for the premature destruction of red cells by the reticuloendothelial system. Chronic hemolyticanemia and frequent vaso-occlusive crises causes damage to various organs and impair both the survival and the quality of life of person with SCD.

The physiological adaptations that occur in the circulatory, hematologic, renal, and pulmonary systems during pregnancy can overburden organs that already have chronic injuries secondary to SCD, increasing the rate of obstetric complications such as eclampsia, pre-eclampsia, DVT as well as the complications of the disease, such as worsening of vasoocclusive crises and acute chest syndrome. ${ }^{4}$ Besides, underlying uteroplacental insufficiency leads to fetal affections like IUGR, IUD, stillbirth, low birth weight, preterm delivery and fetalanemia.

\section{Materials and Methods}

All pregnant women with sickle cell disease who attended ANC clinic in a government tertiary care centre are included in study. Age matched controls are included who had normal haemoglobin, in ratio 1:2. A detailed informed consent is taken from women and her kin regarding participation in the study.
A detailed history taken which included obstetric history, medical and surgical history, blood transfusions and episodes of blood transfusion reactions (BTR) in past. Need for previous hospitalisation if any was noted (apart from hospitalisation required for her prior deliveries). All women were thoroughly examined and were properly followed and managed for any developing complications. Mothers are regularly screened for any developing medical/ obstetric complications throughout pregnancy, during delivery and in postpartum period till the discharge.

All women are investigated for serial haemoglobin levels, serum liver and renal functions, urine routine microscopy, culture sensitivity, obstetric ultrasound as per ANC protocol. Need for hospital admissions, type of complications, requirement of blood transfusion were noted in detail. Blood transfusion was given if $\mathrm{Hb}$ level fell below $8 \mathrm{gm} / \mathrm{dl}$. All the data was filled in the form of proforma.

The fetomaternal outcomes were compared using $P$ value and paired T test whichever was suitable.

\section{Inclusion Criteria}

(1)All Pregnant women who attended department of obstetrics and gynecology, Pt JNM medical college, Raipur were subjected to HB electrophoresis. Those with SS genotypes were included in study as cases. (2) Age and parity matched women who had AA genotypes were recruited as controls.

Exclusion Criteria: Patients having any other hemoglobinopathy and other hemolyticanemias.

\section{Results}

There were 60 cases of SS compared with 120 cases of AA genotype in present study. 
Table 1: Status of epidemiological characteristics of women with and without sickle cell disorder

\begin{tabular}{|c|c|c|c|}
\hline Characteristic & SS $(n=60)$ & $\mathbf{A A}(\mathbf{n}=\mathbf{1 2 0})$ & P value \\
\hline $\begin{array}{l}\text { A) Age at delivery } \\
<\mathbf{2 0} \\
\mathbf{2 1 - 3 0} \\
>\mathbf{3 0}\end{array}$ & $\begin{array}{l}8.3 \% \\
90 \% \\
1.7 \%\end{array}$ & $\begin{array}{c}7.5 \% \\
91.6 \% \\
1.8 \%\end{array}$ & $\begin{array}{c}0.8 \\
0.12 \\
0.16\end{array}$ \\
\hline $\begin{array}{l}\text { B)Residential area } \\
\text { Urban } \\
\text { Rural }\end{array}$ & $\begin{array}{l}83.3 \% \\
16.7 \%\end{array}$ & $\begin{array}{l}80 \% \\
20 \%\end{array}$ & $\begin{array}{l}0.7 \\
0.6\end{array}$ \\
\hline $\begin{array}{l}\text { C) Booked/unbooked } \\
\text { Booked } \\
\text { Unbooked }\end{array}$ & $\begin{array}{l}51.7 \% \\
48.3 \%\end{array}$ & $\begin{array}{l}48.3 \% \\
51.7 \%\end{array}$ & $\begin{array}{l}0.75 \\
0.65\end{array}$ \\
\hline $\begin{array}{l}\text { D) Educational status }{ }^{\mathbf{1}} \\
\text { Illiterate } \\
\text { Literate }\end{array}$ & $\begin{array}{c}8.3 \% \\
91.7 \%\end{array}$ & $\begin{array}{c}8.3 \% \\
91.7 \%\end{array}$ & $\begin{array}{c}0.9 \\
0.86\end{array}$ \\
\hline $\begin{array}{l}\text { E) Occupation } \\
\text { Housewife } \\
\text { Government job } \\
\text { Private job } \\
\text { laborer } \\
\text { farmer }\end{array}$ & $\begin{array}{c}86.6 \% \\
1.6 \% \\
5 \% \\
3.33 \% \\
3.33 \%\end{array}$ & $\begin{array}{l}86 \% \\
1.7 \% \\
5.3 \% \\
3.4 \% \\
3.6 \%\end{array}$ & \\
\hline $\begin{array}{l}\text { H)Hospital admission requirement in past } \\
\text { Required }\end{array}$ & $80 \%$ & $3.4 \%$ & 0.0001 \\
\hline I) Mean number of hospital admissions in past & $2.3 \pm 3.2$ & $0.021 \pm 0.15$ & 0.001 \\
\hline J) Mean hospital admission duration in past & $9.9 \pm 7.9$ & $0.16 \pm 0.97$ & 0.0004 \\
\hline K) Mean blood transfusions in past & $11.31 \pm 2.69$ & $0.03 \pm 0.17$ & 0.0003 \\
\hline L) Total blood transfusion reactions in past & $8.54 \%$ & $11.2 \%$ & 0.04 \\
\hline
\end{tabular}

Table 2 : Distribution of cases according to medical complications in current pregnancy

\begin{tabular}{|c|c|c|c|c|c|}
\hline \multirow{3}{*}{$\begin{array}{l}\text { Medical complications of current } \\
\text { pregnancy }\end{array}$} & \multirow{2}{*}{\multicolumn{2}{|c|}{$\begin{array}{c}\text { Cases } \\
\text { SS }(n=60)\end{array}$}} & \multirow{2}{*}{\multicolumn{2}{|c|}{$\begin{array}{c}\text { Control } \\
\mathbf{A A}(\mathbf{n}=120)\end{array}$}} & \multirow{3}{*}{$\begin{array}{c}\text { P value } \\
\text { SS vs AA } \\
\end{array}$} \\
\hline & & & & & \\
\hline & $\mathbf{N}$ & $\%$ & $\mathbf{N}$ & $\%$ & \\
\hline Painful crisis & 14 & $23.3 \%$ & 0 & $0 \%$ & 0.0001 \\
\hline 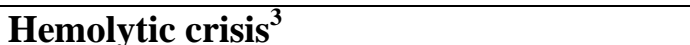 & 30 & $50 \%$ & 0 & $0 \%$ & 0.0001 \\
\hline Jaundice & 29 & $48.3 \%$ & 0 & $0 \%$ & 0.0001 \\
\hline Cholelithiasis & 2 & $3.3 \%$ & 0 & $0 \%$ & 0.019 \\
\hline Aplastic crisis & 1 & $1.6 \%$ & 0 & $0 \%$ & 0.0001 \\
\hline Abdominal crisis & 4 & $6.6 \%$ & 0 & $0 \%$ & 0.0001 \\
\hline Acute chest syndrome ${ }^{4}$ & 5 & $8.3 \%$ & 0 & $0 \%$ & 0.0001 \\
\hline Pneumonia & 4 & $6.7 \%$ & 1 & $0.8 \%$ & 0.016 \\
\hline UTI & 12 & $20 \%$ & 8 & $6.6 \%$ & 0.0006 \\
\hline Chronic renal failure ${ }^{5}$ & 1 & $1.6 \%$ & 0 & 0 & 0.025 \\
\hline Leg ulcers $^{6}$ & 5 & $8.3 \%$ & 0 & $0 \%$ & 0.0001 \\
\hline AVN hip ${ }^{7}$ & 1 & $1.6 \%$ & 0 & $0 \%$ & 0.001 \\
\hline
\end{tabular}

\footnotetext{
${ }^{1}$ Although $91.7 \%$ SS cases were literate, maximum number of cases $23 \%$ had done their schooling upto primary level only.

${ }^{2} 60$ SS cases in total needed 258 hospital admissions in past as against only 3 past admissions in 120 AA cases. Most common reason for hospital admission was anemia. $43 \mathrm{SS}$ cases required admissions between range 1-5. There were 2 cases who needed 7 times hospital admissions. There were 2 cases who required hospital admissions more than 10 times. Chief reason of their admissions was crisis and anemia.

${ }^{3} 29$ cases were managed conservatively by blood transfusions. One unbookedcase had acute haemolytic crisis leading to CCF, shock and death .

${ }^{4}$ One of the 5 cases of acute chest syndrome died inspite of management and ventilator support.

${ }^{5}$ The case of chronic renal failure underwent 4 dialysis in postpartum period and was discharged after recovery.

${ }^{6} 5$ cases of 60 had superficial chronic leg ulcers which were healed by regular wound care in 7 to 10 days.

${ }^{7}$ The case of AVN hip had leg deformity.
} 


\begin{tabular}{|l|c|c|c|c|c|}
\hline $\mathbf{C C F}^{\mathbf{8}}$ & 3 & $5 \%$ & 0 & 0 & 0.0001 \\
\hline Shock $^{9}$ & 4 & $6.6 \%$ & 0 & 0 & 0.0001 \\
\hline $\begin{array}{l}\text { Blood transfusions required during } \\
\text { antenatal period }\end{array}$ & 28 & $48.3 \%$ & 13 & $11 \%$ & 0.0001 \\
\hline Blood transfusion required during labor & 40 & $66.6 \%$ & 7 & $5.8 \%$ & 0.0001 \\
\hline Need of ventilatory support & 5 & $8.3 \%$ & 0 & 0 & 0.0001 \\
\hline Death & 3 & $5 \%$ & 0 & 0 & 0.0015 \\
\hline
\end{tabular}

Table 3: Distribution of cases according to obstetric complications of current pregnancy

\begin{tabular}{|l|c|c|c|c|c|}
\hline \multirow{2}{*}{} & \multicolumn{2}{|c|}{ Cases SS (n=60) } & \multicolumn{2}{c|}{$\begin{array}{c}\text { Controls AA } \\
(\mathbf{n = 1 2 0})\end{array}$} & \multirow{2}{*}{ P value } \\
\cline { 2 - 6 } & $\mathbf{N}$ & $\mathbf{\%}$ & $\mathbf{N}$ & $\mathbf{\%}$ & \\
\hline Toxemia of preganancy & 8 & $13.33 \%$ & 6 & $5 \%$ & 0.040 \\
\hline Eclampsia & 2 & $3.3 \%$ & 2 & $1.6 \%$ & 0.47 \\
\hline HELLP & 2 & $3.3 \%$ & 3 & $2.5 \%$ & 0.26 \\
\hline Anemia in pregnancy & 28 & $48.3 \%$ & & & \\
\hline Abruption & 2 & $3.3 \%$ & 1 & $0.8 \%$ & 0.019 \\
\hline Severe oligohydramnios ${ }^{\mathbf{1 0}}$ & 16 & $26.6 \%$ & 5 & $4.16 \%$ & 0.0001 \\
\hline Severe IUGR ${ }^{\mathbf{1 1}}$ & 15 & $25 \%$ & 6 & $5 \%$ & 0.0001 \\
\hline Abortion ${ }^{\mathbf{1 2}}$ & 1 & $1.6 \%$ & 0 & 0 & 0.001 \\
\hline Preterm ${ }^{\mathbf{1 3}}$ labor & 10 & $16.6 \%$ & 2 & $1.6 \%$ & 0.0001 \\
\hline Post delivery wound infection & 4 & $10.5 \%$ & 6 & $5 \%$ & 0.008 \\
\hline $\begin{array}{l}\text { Mean duration of hospital } \\
\text { stay }\end{array}$ & \multicolumn{2}{|l|}{$12.23 \pm 5.26$} & $2.08 \pm 1.13$ & 0.001 \\
\hline
\end{tabular}

Table 4 : Neonatal outcome in current pregnancy

\begin{tabular}{|l|c|c|c|c|c|}
\hline \multirow{2}{*}{} & \multicolumn{2}{|c|}{ Cases SS (n=60) } & \multicolumn{2}{c|}{$\begin{array}{c}\text { Controls } \\
\mathrm{AA}(\mathrm{n}=120)\end{array}$} & SS vs AA \\
\cline { 2 - 6 } & $\mathrm{N}$ & $\%$ & $\mathrm{~N}$ & $\%$ & \\
\hline Live birth & 51 & $85 \%$ & 120 & $100 \%$ & 0.0001 \\
\hline IUD $^{14}$ & 4 & $6.6 \%$ & 0 & $0 \%$ & 0.001 \\
\hline Still birth $^{15}$ & 5 & $8.3 \%$ & 0 & $0 \%$ & 0.01 \\
\hline Early neonatal death $^{16}$ & 11 & $18.3 \%$ & 3 & $2.5 \%$ & 0.0001 \\
\hline $\begin{array}{l}\text { Low birth weight } \\
\text { babies }\end{array}$ & 25 & $41.6 \%$ & 8 & $6.6 \%$ & 0.0001 \\
\hline Birth asphyxia & 16 & $31.37 \%$ & 9 & $7.5 \%$ & 0.001 \\
\hline Nursery admission & 21 & $41.17 \%$ & 10 & $8.3 \%$ & 0.001 \\
\hline
\end{tabular}

\footnotetext{
${ }^{8} 3$ cases had CCF. One due to haemolytic crisis, other due to severe anemia and third due to acute chest syndrome. All the 3 cases died

${ }^{9}$ Out of 4 cases of shock, one case had severe anemia leading to shock and death. $2^{\text {nd }}$ case had haemolytic crisis leading to shock and death. The case of abortion had crisis followed by incomplete abortion leading to shock. She was revived and got cured. One case of severe preeclampsia and severe anemia had postpartum collapse .she was revived by blood transfusion. All 4 were unbooked cases.

${ }^{10}$ Oligohydramnios developed in 11 cases in early $3^{\text {rd }}$ trimester. 4 of 11 were unbooked cases presented with IUD. 7 of 11 were managed by conservative management. 5 cases developed oligohydramnios near term. They were terminated by elective LSCS.

${ }^{11}$ As the present study is carried out in a medical college, dating scan, 3rd

trimester uterine artery dopplar and a ultrasound scan before delivery was done in each booked case.

${ }^{12}$ One case of SS whose partner was also SS developed painful crisis in 10 th week of gestation followed by abortion.

${ }^{13} 4$ were induced and 6 were due to spontaneous onset. 1 induction was done for imminent eclmapsia in $2^{\text {nd }}$ trimester. 3 were preterm LSCS .one for severe preeclampsia and 2 for severe IUGR and anhydramnios.

${ }_{14}^{14} 1$ IUD was due to severe anemia and abruption, 2 due to painful crisis, 1 due to IUGR with anhydramnios.

${ }^{15}$ Prematurity was reason for 1 stillbirth. 3 babies died due to meconium aspiration. 1 due to prolonged $2^{\text {nd }}$ stage of labor.

${ }^{16} 5$ babies died due to respiratory distress syndrome due to preterm delivery. 4 babies had neonatal jaundice leading to death. 1 baby had meconium aspiration and 1 baby had septicaemia.
} 


\section{Discussion}

SCD can increase complication during pregnancy and in turn negatively influence the pregnancy outcomes. It is well established that women with SCD have an increased risk of maternal and fetal complications during pregnancy compared with healthy women. ${ }^{5}$ This is due to chronic hypoxia and vaso-occlusive phenomena that occur in the microcirculation, both maternal and fetal. Pregnancy allows acute complications such as sickle cell vaso-occlusive crises, acute chest syndrome, or severe chronic anemia ${ }^{6}$ Maternal death rate due to sickle cell diseases in pregnancy is up to $11.4 \%$. Formerly discouraged, motherhood has increased among women with major sickle cell syndrome because of the considerable progress made in the management of this disease ${ }^{7}$ With advances in hematological management, women with hemoglobinopathies enjoy an increased life expectancy hence it is increasingly common for these women to live long enough to reach childbearing age and to become pregnant.

Mean age of cases in present study was 24.3 years. In addition to suffering due to disease, families of sicklers carry great financial hardships too and there is overall apathy of society towards women health, leading $48.3 \%$ cases had not attended atenatal checkups. $65.8 \%$ cases were referred directly for management of complications. Most common reason for referral was anemia. Medical and surgical complications of sickle cell disease demand more frequent hospital admissions among cases. In present study, it was observed that a vast majority of women with sickle cell disease required admission in past (48/60) as against only (7/300) in AA group. Total number of hospital admissions among these 60 women with SS was 258 as against 7 in 300 AA cases. The mean number of hospital admission was statistically highly significant among women with SS as against AA being $2.3 \pm 3.2$ (SS) vesus $0.023 \pm 0.15$ (AA). Mean duration of hospital stay in past life was $9.9 \pm 17.91$ among sickle cell disease cases and $0.13 \pm 0.95$ among AA cases. Management of anemia, crisis, jaundice, oligohydramnios and preeclampsia were major reasons for hospital admissions.

Every blood donation is a gift of life and Blood transfusion remains the cornerstone in management of sickle cell disease. In present study, there were 679 blood transfusions in past 10 years in $60 \mathrm{SS}$ cases. There was one case who had required 124 blood transfusions since childhood and 20 hospital admissions. Blood contains over 100 other minor blood subtypes. These can lead to erythrocyte alloimmunization with serious complications for the patient. The most serious consequence of alloimmunization in SCD patients is the risk of developing a delayed hemolytic transfusion reaction (DHTR), which can be life-threatening. 58 BT reactions occurred in past in these cases. Making BTR rate 8.54\%.23.3\% cases had painful crisis in current pregnancy

Definition of painful crisis in present study included symptomatic women who required analgesic therapy and hospital admission. Percentage of patients suffering from painful crisis among SCD population range between $14 \%$ to $77.8 \%$ in various studies. $23.3 \%$ cases had painful crisis in current pregnancyin present study. The incidence of hemolytic crisis in present study was $50 \%$ which was higher than various other studies. Hence, and due to various acute events, $48.3 \%$ cases required blood transfusions in antenatal period. Equal number of cases $66.6 \%$ needed blood transfusions during labour due higher rates of haemolytic observed in perinatal period. Not much literature is available regarding higher hemolysis rates in Indian SCD population.

The acute chest syndromeis a vaso-occlusive crisis of the pulmonary vasculature and deadly complication leading to mortality between 9$25 \% .^{8}$ Acute chest syndrome was present in $8.3 \%$ patients in sickle cell disease in present study. Similar results are obtained by Nomura et $\mathbf{a l}^{\mathbf{9}}$ Maternal mortality rate in present study was $5 \% .2$ patients died due to severe anemia out of which one died in antenatal period. One patient died of 
acute chest syndrome, CCF, DIC and ventilatory support were the antecedent events in all 3 deaths. Maternal mortality rates in present study are similar to most of the other studies. Higher mortality rates $(11.4 \%)$ are obtained by Muganyizi et al (Nigerian study). ${ }^{\mathbf{1 0}}$ Overall, maternal mortality rate is higher in Nigeria than India. Aplastic crisis occurs due to parvovirus B19 infection. It is rare in adults. In our study, aplastic crisis occurred in 1 case which was managed by blood transfusions.UTI occurred in $20 \%$ SS patients in present study. Results similar to present study was obtained by Al Jama, Nomura 2010 et al $(25.5 \%)$ and Siva 2014 et al (2012) (23\%). ${ }^{11,12,13}$

Sickle cell disease is proposed to be chronic inflammatory state. Endothelial damage secondary to sickled red blood cells and subsequent release of proinflammatory cytokines may contribute to microvascular damage. Normal vascular, endothelial, inflammatory adaptations in pregnancy may lead to exacerbations of these pathophysiological changes. With manifestations of resulting maternal complications such as preeclampsia and fetal growth restriction. ${ }^{\mathbf{1 4}} 13.3 \%$ of SS women had toxemia of pregnancy which was significant than AA women. The results comparing toxemia of pregnancy in sickle cell disease and trait are contradictory in literature. 2 cases of 8 had eclampsia .percentage of cases getting complicated by eclampsia are higher in studies by Khandale et al (2015) ${ }^{\mathbf{1 5}}$ and Sonawne et al $(\mathbf{2 0 0 5})^{\mathbf{1 6}}$. In both these studies, rates of preeclampsia are higher as well. Lower rates of preeclampsia in present study might be due to younger population and low BMI of the cases.

SS women are at greater risk for being anemic. The mean haemoglobin at the time of registration in study in SS cases was $6.4 \pm 2.67 \mathrm{~g} / \mathrm{dL}$, which was far lower than AA cases $(9 \pm 1.8)$. Finding is similar to study conducted by SN Khandale. Anemia in pregnancy has been found to be associated with increased risk for, spontaneous preterm labor, preterm delivery, poor intrauterine growth, and LBW infants. ${ }^{17}$ In present study incidences if low birth weight, prematurity, IUGR, IUD, stillbirths and birth asphyxia were significantly higher in babies of SS than AA women. $41.6 \%$ babies born to SS mothers were LBW in present study. Similar results are given by other Indian studies like Kale et al and patel et al. ${ }^{18}$ Study by sonawne et al have found higher rate of preterm delivery and preeclampsia than present study which could be the reason for higher low birth weight in their study.

IUGR reflects an infant who has been unsuccessful in attaining his or her personal optimum growth. Recent research have found association between SCD and abnormal placental histology including placental lesions of moderate to severe villous sclerosis, intervillous fibrin deposits and infarction and birth of IUGR baby. ${ }^{19}$ Incidence of IUGR in present study was $25 \%$. This is lower than study by Kahansim $\mathbf{M L}^{\mathbf{2 0}}$. Study by this author has more crisis incidence than present study.

Sickle cell hemoglobinopathy is a common disease in central India. pregnancy with sickle cell disease is bound to be associated with feto maternal complications. Vaso occlusive crisis, anamia, preeclampsia. More requirement of blood transfusion, longer mean duration of hospital stay were main maternal complications in our study. IUGR, IUFD, prematurity, low APGAR scores were found as main fetal complications in our study requiring more NICU admission of neonate. Many of cases in our study were unbooked. Fetomaternal outcomes in booked cases were better than unbooked ones. Early booking, meticulous antenatal care and supervised hospital delivery will improve the maternal and fetal outcomes in the pregnant women with sickle cell disease.

\section{References}

1. Rees DC, Williams TN, Gladwin MT. Sickle-cell disease. Lancet. 2010;376 (9757):2018-2031. doi: 10.1016/S01406736(10)61029-X. 
2. Weatherall D. The inherited disorders of haemoglobin: an increasingly neglected global health burden. Indian J Med Res. 2011;134(4):493. [PMC free article] [PubMed]

3. Sickle Cell Institute Chhattisgarh (SCIC), Raipur.

4. Koshy M, Burd L. Management of pregnancy in sickle cellsyndromes. Hematol Oncol Clin North Am. 1991;5(3):585-96.8

5. Serjeant GR, Loy LL, Crowther M, Hambleton IR, Thame M. Outcome of pregnancy in homozygous sickle cell disease. Obstet Gynecol. 2004;103(6): 1278-1285. doi: 10.1097/01. AOG.0000127433.23611.54.[PubMed] [Cross Ref

6. Centre de Reference Maladies rareslabellisées (2007) Syndrome drépanocytaire majeur. Recommandations pour la prise en charge de la grossesse chez les femmesatteintes d'un syndrome drépanocytaire majeur.

7. Centre de Reference Maladies rareslabellisées (2007) Syndrome drépanocytairemajeur. Recommendations pour la prise en charge de la grossesse chez les femmesatteintes d'un syndrome drépanocytaire majeur.

8. Platt OS, Brambilla DJ, Rosse WF, Milner PF, Castro O, Steinberg MH, Klug PP. Mortality in sickle cell disease. Life expectancy and risk factors for early death. N Engl J Med 1994;330:1639-1644 [PubMed]

9. Nomura R, Igai A, Tosta K, Fonseca G, Gualandro S, Zugaib M. Resultados maternos e perinatais emgestações complicadas pordoenças falciformes. Revista Brasileira de Geofísica. 2010;32(8).

10. Muganyizi P, Kidanto H. Sickle Cell Disease in Pregnancy: Trend and
Pregnancy Outcomes at a Tertiary Hospital in Tanzania.PLoS ONE 2013;8(2):e56541.

11. Al Jama F, Gasem T, Burshaid S, Rahman J, Al Suleiman S, Rahman M. Pregnancy outcome in patients with homozygous sickle cell disease in a university hospital, Eastern Saudi Arabia. Archives of Gynecology and Obstetrics. 2009;280(5): 793-797.

12. Nomura R, Igai A, Tosta K, Fonseca G, Gualandro S, Zugaib M. Resultados maternos e perinataisemgestações complicadaspor doenças falciformes. Revista Brasileira de Geofísica. 2010;32(8).

13. Silva-Pinto A, de Oliveira DominguesLadeira S, Brunetta D, De Santis G, de LucenaAngulo I, Covas D. Sickle cell disease and pregnancy: analysis of 34 patients followed at the Regional Blood Center of RibeirãoPreto, Brazil. RevistaBrasileira de Hematologia e Hemoterapia. 2014;36(5):329-333.

14. Oteng-Ntim E, Meeks D, Seed PT, Webster L, Howard J, Doyle P, et al. Adverse maternal and perinatal outcomes in pregnant women with sickle cell disease: systematic review and metaanalysis. Blood. 2015;125:3316-25.

15. Khandale S, Kedar K. A Study Of Sickle Cell Trait Complications In Pregnancy \& Delivery At Tertiary Level Center. Journal of Evolution of Medical and Dental Sciences. 2015;04(11):1831-1835.

16. SonawneA, Zodpey S. pregnancy outcome in women with sickle cell disease / trait. J Obste tGynocol India. 2005; vol. 55(No 5):415-418.

17. Allen LH.Anemia and iron deficiency: effects on pregnancy outcome. Am J ClinNutr. 2000;71:1280S-1284S. [PubMed]

18. Patel M, Shrivastava A, Desai D. Perinatal outcome in women with sickle cell 
disease/trait. Global Journal For Research Analysis. 2014;3(12):2277- 8160.

19. Anyaegbunam A, Mikhail M, Axioitis C, Morel MI, Merkatz IR. Placental histology and placental/fetal weight ratios in pregnant women with sickle cell disease: relationship to pregnancy outcome. $\mathbf{J}$ Assoc Academic Minority Physicians. 1994;5(3):123-125.

20. Kahansim ML et al. pregnancy outcome among patients with sickle cell disease in jos, north central nigeria. Jos Journal of Medicine. 2014;8(3):9-13. 